\title{
Braided Streams: Spaces and Flows in a Career
}

\section{Janice Monk}

University of Arizona. School of Geography and Development.

Southwest Institute for Research on Women

jmonk@email.arizona.edu

Received: July 2014

Accepted: July 2014

\begin{abstract}
In accordance with the proposal by the Department of Geography, Dr. Janice Monk, professor emerita at the University of Arizona, was awarded Doctor Honoris Causa by the Universitat Autònoma de Barcelona on the October $16^{\text {th }}$ 2013. A slightly edited version of the lecture she presented at the ceremony is published here. Dr. Monk has been a key figure in fostering gender geography in the United States as well as internationally. Here she reflects on her academic and professional career, focusing on the principal topics that have characterised her research and her social involvement. A bibliography of her main contributions is attached to the text of her lecture.
\end{abstract}

Keywords: Janice Monk; Geography; gender; professional career.

\section{Resum. Rius trenats. Espais i fluxos en una carrera acadèmica}

El 16 d'octubre de l'any 2013 la Universitat Autònoma de Barcelona, a proposta del Departament de Geografia, va concedir el doctorat honoris causa a la Dra. Janice Monk, professora de la Universitat d'Arizona. En aquesta contribució especial s'ha reproduït, amb alguna adaptació posterior, el discurs pronunciat per la Dra. Monk en aquella data. La professora Janice Monk ha estat una figura cabdal en el desenvolupament de la geografia del gènere tant als Estats Units com internacionalment. En aquestes línies reflexiona sobre la seva trajectòria acadèmica i professional, les temàtiques que han marcat les seves reflexions com a investigadora i el seu compromís social. Aquest article es completa amb una bibliografia que recull les seves principals contribucions.

Paraules clau: Janice Monk; geografia; gènere; trajectòria professional. 
Resumen. Cauces trenzados. Espacios y flujos en una carrera académica

El 16 de octubre del año 2013 la Universitat Autònoma de Barcelona, a propuesta del Departamento de Geografía, concedió el doctorado honoris causa a la Dra. Janice Monk, profesora de la Universidad de Arizona. En esta contribución especial se ha reproducido, con alguna adaptación posterior, el discurso pronunciado por la Dra. Monk en aquella fecha. La profesora Janice Monk ha sido una figura capital en el desarrollo de la geografía del género tanto en Estados Unidos como internacionalmente. En estas líneas reflexiona sobre su trayectoria académica y profesional, las temáticas que han marcado sus reflexiones como investigadora y su compromiso social. Este artículo se completa con una bibliografía que recoge sus principales contribuciones.

Palabras clave: Janice Monk; geografía; género; trayectoria profesional.

Résumé. Rivières en tresses. Les espaces et les flux dans une carrière académique

Le 16 Octobre 2013, l'Universitat Autònoma de Barcelona, sur proposition du Département de géographie, a décerné le Doctorat Honoris Causa à Mme Janice Monk, professeur à l' University of Arizona. Cet article est une reproduction adaptée du discours prononcé par la professeur Monk ce jour-là. Janice Monk a joué un rôle primordial dans le développement de la géographie du genre aux États-Unis et au niveau international. Dans ces lignes, nous nous penchons sur sa carrière académique et professionnelle, sur les thèmes qui ont marqué ses réflexions en tant que chercheur et sur son engagement social. Cet article est livré avec une bibliographie donnant les principales contributions.

Mots-clé: Janice Monk; géographie; genre; carrière professionnelle.

\section{Summary}

Persistent Priorities: Social equity and inclusivity, women and gender, valuing the international

Social Relations and Inequalities
Women, Gender, and Feminist Studies

Changing Institutions

Bibliographic references

The worlds of Geography are indeed diverse, and one sometimes wonders what holds them together. There are certainly a number of widely held views and concerns, most recently regarding issues related to globalisation and to environmental change. But while participating in the International Geographical Congress in Japan in 2013, I could not help wondering what it is that leads individual geographers to carry out the work they pursue and the places in which they undertake their research. Why would a Japanese scholar study nomadic pig herding in Bangladesh, a British woman reflect on gender, indigeneity, and environmental values in Ecuador, or a Taiwanese examine the sustainability of rural systems in Israel? Biographical and autobiographical studies by a number of geographers offer insights into the ways in which personal values, contexts, encounters and the evolving discipline come together and play 
out in research and professional work (Barnes, 2001; Moss, 2001; Aitken and Valentine, 2006; King, 2007). With that theme in mind, in this paper I adopt an approach that has been identified as auto-ethnographic. I invoke "braided streams" as a metaphor, drawing on a concept from physical geography of a stream form that is characterised by divergent and convergent channels.

\section{Persistent Priorities: Social equity and inclusivity, women and gender, valuing the international}

Three channels characterise the bulk of my work: concerns for social equity and inclusivity, issues of women and gender, and the valuing of international ties. These have involved aspects of research, teaching, and engagement with professional service in order to prompt institutional change. The channels diverge and converge.

In examining these streams, I acknowledge an idea that has become widely discussed in contemporary human geography, especially in feminist studies: i.e. that the "positionality" of the researcher and the contexts in which the work is being done are significant influences on practice. Clearly, attention to women and gender emerged as a significant theme in the profession in the 1970s, reflecting the women's political movements of the time, uneven as they were in space and time. Yet before turning to that period, I begin with some references to place, specifically to an experience at the Universitat Autònoma de Barcelona, where in 1993 I gave a lecture entitled "Place Matters" and which was subsequently published (Monk, 1994). It was given at a European Union supported ERASMUS course, one that brought together geography students and staff from the Autònoma with others from Denmark, Greece, the Netherlands, and the UK. They learned with and from each other about different ways of acquiring knowledge and how to work together. My lecture explored where and how geographers at that time were engaging with gender studies; drawing examples not only from the dominant but differing Englishspeaking approaches in Britain and the US, but also from scholarly traditions such as the Spanish rural studies and the Dutch focus on social policy and planning. Among other examples, I noted how economic development and ethnic divisions were shaping research in Sri Lanka, and asked why there remained a general absence of interest in gender in the otherwise strong geographical communities of Germany and East Asia. Since that time, patterns and practices have changed, but the larger question remains: how do political and social contexts and scholarly traditions, as well as the visions of individual scholars, shape the creation and dissemination of knowledge?

Reflection on how place and people matter and are connected also takes me back to Barcelona in 1986. This was my introduction to the city, when I chaired the first research session ever held on gender at an International Geographical Union (IGU) Regional Congress. It followed an informal gathering at the IGU Congress in Paris in 1984 at which the potential for a gender network was discussed. At the Barcelona Congress, with the support of Maria 
Dolors Garcia Ramon, who was on the Congress organising committee, and whom I had met in 1984, and with the assistance of Gemma Cànoves, then a postgraduate student, we organised a half-day round table to explore directions in gender studies in geography as revealed in several contexts. I recall dreaming the night before that speakers would not accept each other's ideas, claiming that the "right" approaches were those practiced in their own settings. As it turned out, that particular dream did not come true, and the collegiality in the well-attended session was a precursor for placing gender within the channels of the IGU.

I will not take you through the details of the intervening decades, but rather just offer some idea of the extent to which feminist perspectives and gender themes have spread in geography. Over the last 25 years, the Commission on Gender and Geography has become one of the most active groups within the International Geographical Union (IGU). Its electronic mailing list includes over 600 people. It regularly participates in the IGU's international meetings, and in recent years has hosted or co-hosted numerous thematic conferences, including events in Brazil, India, New Zealand, Singapore and Taiwan, and one that straddled the Hungarian/Romanian border. Each event has connected the perspectives of local geographers with those from other countries. Among other significant events was the 2006 conference devoted to exploring "Feminist Geographies around the World."(Garcia Ramon and Monk, 2007), which brought together people from 14 countries to reflect on the histories and directions of work in their own settings. Recognition of the Commission's endeavours and productivity was confirmed by its selection in 2014 by the IGU as the Commission which most successfully meets the organisation's declared mission.

The breadth and vibrancy of the field is revealed by the diversification of its conceptual, methodological and topical approaches. For example, at the 2013 annual meeting of the Association of American Geographers, a conference now attended by scholars from a wide range of countries, the group that specialises in gender co-sponsored sessions with over 20 other groups whose thematic interests included, among others, historical and urban geography, health, sexuality, children, and problems of coastal environments. The work involved methodologies and techniques ranging from GIS to socialist perspectives and qualitative interpretations of emotions. One might wonder, do the braided channels of gender studies in geography converge? There are indeed recurring perspectives, including the ones that have I noted and that I value. To understand how these may come together over the course of a professional career, and how braided streams can overlap and converge, I return to my own work, referring to personal contexts and directions in the discipline and beyond.

\section{Social Relations and Inequalities}

The research for my doctoral studies in Geography in the United States goes back to the mid-1960s. My dissertation dealt with the social and economic 
lives of people of Aboriginal descent in small towns in south-eastern Australia. At that time, neither Australian nor American geographers were engaging with indigenous communities, but were increasingly focusing on testing spatial theories and exploring quantitative methods. However, personal life can shape our academic choices. I had grown up in an Australia where the dominant British heritage that had permeated most of our education was being questioned, as immigration from Europe, especially from Italy and Greece, was introducing cultural diversity and raising issues of ethnic relations. Government policies towards Aboriginal people did not arouse much public interest, although they were articulated in terms of "assimilation" into white society. What Aboriginal people might think was not a major concern. A friend, however, recruited me to participate in a summer work project in which young people, many of them recent university graduates, volunteered their labour to construct a house for an Aboriginal family in a white neighbourhood in a small rural town. Situated within the assimilation framework, it was conceived to improve the housing conditions of Aboriginal people. My participation in that project led to my thinking more about who decides who lives where, how this family would fare in isolation in their new neighbourhood, and what their new place might mean for their own community.

Shortly after that experience, having moved to study in the United States, I was also beginning my research at a time when civil rights and race issues were central in American society. The braided streams began to merge for me. I took courses in anthropology and sociology on culture change and race relations, yet retained my geographic viewpoint that place mattered. I returned to Australia for my doctoral dissertation research in a set of small Australian towns in which Aboriginal people, mostly of part-Aboriginal heritage going back several generations, were a minority element in the population. The towns were selected on the basis of their demographics and economies, holding the demographics relatively constant and varying the economies. The research revealed that the spatial isolation of Aboriginal families was pervasive, with a wide range of consequences. Government-built houses were inadequate, too small, too few, and generally not contiguous with other parts of the community. Self-built makeshift dwellings commonly lacked access to good water and sanitation. Opportunities for Aboriginal employment were limited by stereotypes, discrimination and lack of education. Yet life for Aboriginal people also differed between the towns (Monk, 1974) reflecting, among other contributing factors, the types of employment available to men and also whether women were able to participate in the workforce.

For a variety of reasons, not least the difficulty of doing research in Australia while based in the US, after completing my doctorate I turned to other themes. However, I saved all the original field material, and recently the braided streams have come together. Geographers internationally, and in Australia, are showing more interest in indigenous studies. In this context, my materials from 1965, including the household interviews, field notes, photographs and correspondence are of contemporary interest as a base line for assessing the 
impacts of subsequent changes in government policies on community life. With colleagues at Macquarie University in Australia, I am engaging in collaborative work with those same communities. My original materials have been archived at the Australian Institute of Aboriginal and Torres Strait Islander Studies as a resource, and work is in progress to explore the implications of subsequent changes in social policies and local demographic and economic changes. This gave me the opportunity to revisit some of those communities in 2011 and 2014 to meet with Aboriginal people and find out about the new institutions in which they are involved, to review their own histories and to strive for social change. The new research demonstrates some traits that were not common in geography in the 1960s, especially addressing approaches to dealing with groups considered to be vulnerable, such as indigenous populations. Participatory community approaches to research have become more widely employed, and local people are now involved in exploring directions for community action. Thus the present stream does not replicate the past work, but draws on and reflects on it.

\section{Women, Gender, and Feminist Studies}

I turn now to the sustained branch in my braided stream - work on women, gender, and feminist perspectives. Early on it examined the goals, methods, and purposes of research, explored the diversity of women, and engaged with interdisciplinary collaboration. Its impetus reflected my experiences as one of the few women entering professional geography in the US, as well as the changing political and social milieu of the 1970s and 80s. One of my first pieces (Monk and Hanson, 1982) was entitled "On Not Excluding Half of the Human in Human Geography." It addressed lacunae in theories, concepts, and methods in geographic research drawing examples from many subfields. This article originated not only in the feminist politics of the time but was also stimulated by the writings of feminist scholars in literature and in history, and the emerging programs in women's studies with which I became increasingly familiar upon moving from a Department of Geography in the Midwestern US to the Southwest Institute for Research on Women (SIROW) at the University of Arizona. The rationale represented by the Institute, and the ways in which its programs developed, illustrate my theme of braided streams. They emphasise the significance of places and their cultures.

SIROW was created as an interdisciplinary and regional research and outreach centre designed to bring together scholars from four states in the region - Arizona, Colorado, New Mexico and Utah. Its agenda involved focusing on the diversity of women in this region, to include not only AngloAmericans but also Mexican Americans and American Indians. The founders thought that addressing this cultural diversity would widen American feminist studies. Up to that time, interpretations of the region had been dominated by the creative works of men, with visions of the land as a virgin to be conquered, as a nurturing mother, as a place for development, or conversely, as a wilderness 
to be protected. Vera Norwood of the University of New Mexico and I put together an interdisciplinary team of feminist scholars who discovered that the visions of the women writers and artists focused on drawing energy from the land and celebrated its wildness and sensuality. Specific cultural and ethnic identities, languages, and geographies were pervasive in framing their visions (Norwood and Monk, 1987), as was a film created by the British film maker Shelley Williams (1995). The film, The Desert is No Lady, illustrates how senses of place and thought are intertwined, reflecting the women's life experiences and their ways of looking at and representing the world. In one scene, Pat Mora, a Mexican American poet, reflects on how her life in a border city shaped her identity and ways of looking at the world:

I'm a native El Pasoan, second generation. My mother was born in this border city, my father came over when he was three years old from Chihuahua, which is a city in Northern Mexico. I think I've been strongly influenced by living in this contentious space, the friction, that spot where these two nations rub together, one nation, a very wealthy powerful nation, the other nation that has struggled to maintain its identity, being bombarded by our constant roar from this side. I think it has shaped my whole view of life to look across where I could have been born had my grandparents not come to this side at the time of the Mexican Revolution.

Likewise, Navaho poet, Lucy Tapahonso, tells how she finds her voice in the landscape of her Native American culture.

The sources for my writing are here in Shiprock but also in the Navajo nation in general. It has to do with the light here, how the sun is, the kind of plants there are, the soil. It has to do with the way that people talk, both in Navajo and in English, and it has to do with the way people perceive language, which is very different from the way non-Navajo perceive language. In Navajo they say everything that a person says is blessed with different kinds of wind, and that a person contains almost the whole atmosphere within them. And so when you say something, then it's not just you, it's like the whole world is talking. So it has to do with honoring language, that it has the ability to change things, to create. It's like in our stories we see that we were created by language.

Another channel in this stream of my personal work emerged when I began to think about gender in landscapes as represented by the public monuments and sculptures around the world. The impetus came from an invitation to write a chapter on gender and landscape for a cultural geography textbook (Monk 1992). How, I wondered, could students begin to see that the landscapes around us are gendered. The ways in which human bodies were portrayed stimulated a variety of questions, for example, in what poses are figures presented, with what abstract values are they associated, and who is responsible for placing the sculptures in the public place? I now have a large collection of images, and offer just a few examples, some from my local Tuc- 


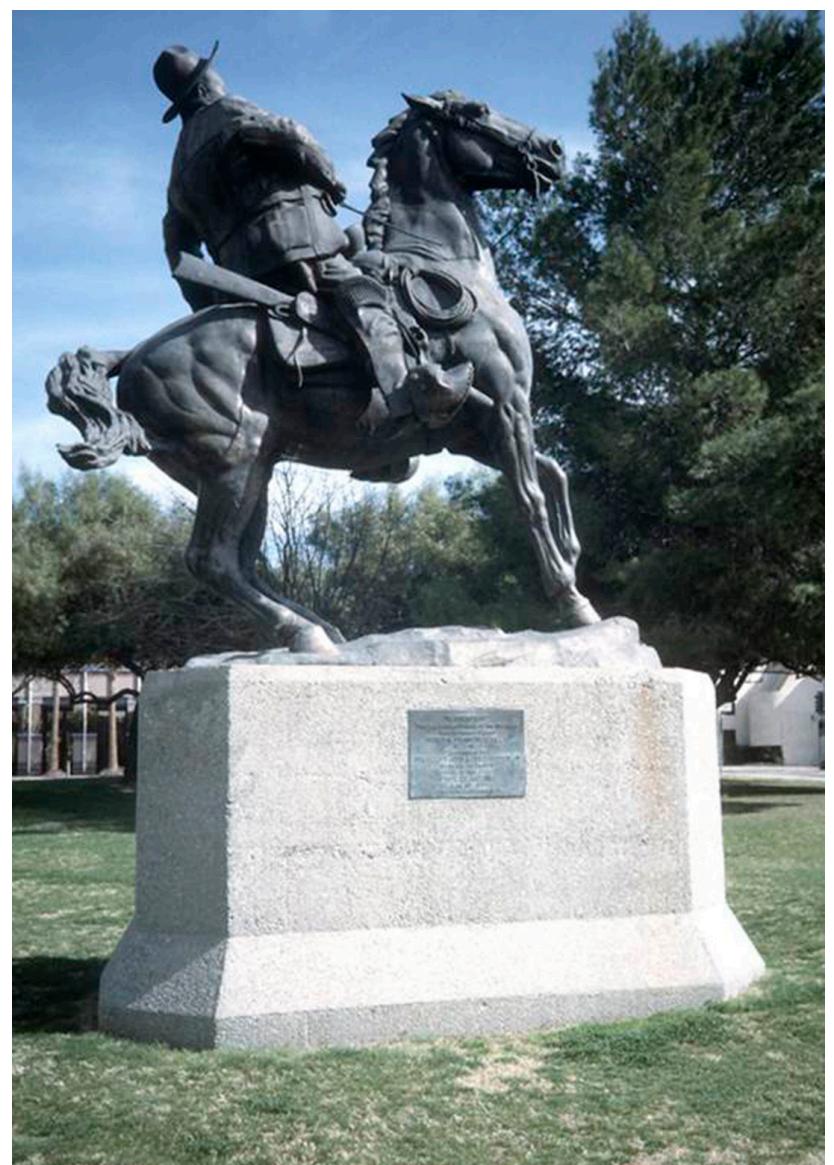

Figure 1. Pancho Villa. General in the early 20th century Mexican Revolution. Located in a park in the city of Tucson. Like many commemorations of men of power, the figure is astride a horse, with the pose of the horse also representing strength and vigour.

Source: Janice Monk, 2010.

son setting, and others from cities around the world (Figures 1-5). Though feminist geographers in recent years have developed a substantial literature on representations and experiences of the body, they have not widely explored this perspective, yet I find it to be one that illustrates the intersections of gender with time, place, power and politics, and also a means of focusing attention on our taken-for-granted landscapes. I entitled the section of my book chapter "Of heroes and horses, myths and maidens" reflecting the pervasive noble and commanding representation of male politicians, explorers and warriors, and the more submissive, often seated and nude, figures of women 


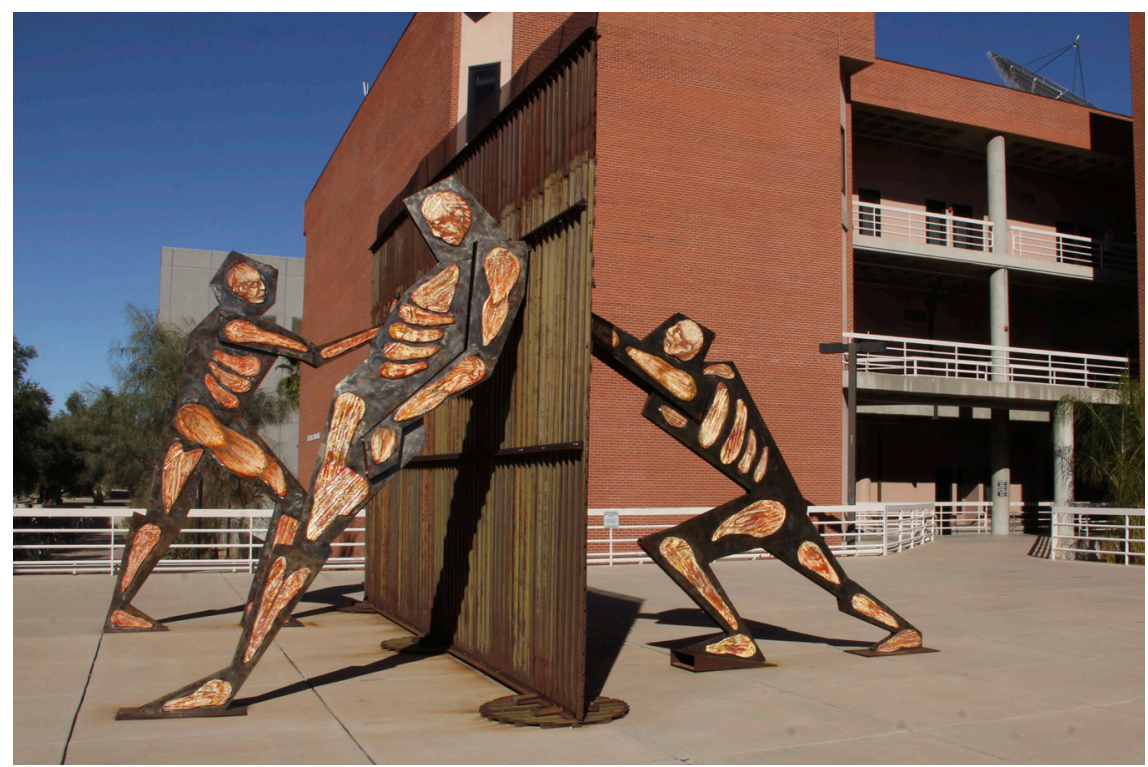

Figure 2. "Border Dynamics". On each side are two male figures, one pushing against the wall, the other leaning against it. In this image, only three of the four figures could be shown. The sculpture invokes tensions about undocumented migration from Mexico and Central America into the US. Although all four figures represented are male, a major contemporary issue is the large scale presence of women and unaccompanied children among those attempting migration.

Source: Janice Monk, 2015.

representing abstract values. Aspects of social class may also be evident. When women are portrayed as political actors, the monument is likely to have been erected by a women's group.

Throughout this feminist work, I have maintained a strong interest in exploring and promoting international connections and perspectives, both in the content and contexts of my writing and developing professional relationships. Janet Momsen and I, for example, initiated a series of books published by Routledge under the title "International Studies of Women and Place" which now includes over 30 volumes, among them Women of the European Union: The Politics of Work and Daily Life (Garcia Ramon and Monk, 1996), Female Sex Trafficking in Asia (Samarasinghe, 2008) and Gender and Agrarian Reforms (Jacobs, 2010).

\section{Changing Institutions}

The final recurring strand of my work that I'd like to address relates to aspects of changing institutions. Currently many are facing difficult political and 

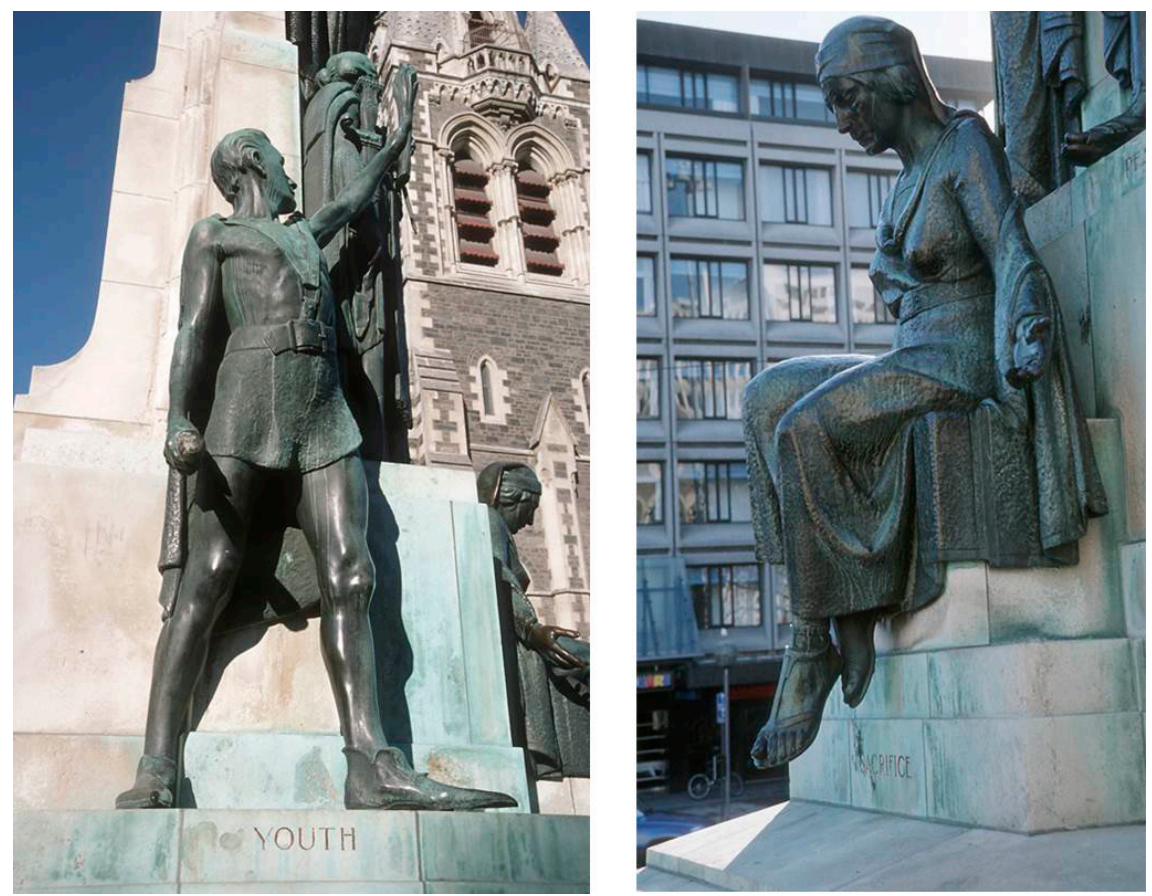

Figures 3 and 4. World War I Memorial, Christchurch, New Zealand. The vigorous standing male figure represents "Youth," the seated female with bowed head, represents "Sacrifice." Such distinctions in the bodily poses of male and female figures are common in public monuments.

Source: Janice Monk, 1998.

financial challenges. I would like to refer to just a few examples; some that identify problems, others that address approaches to bringing about change. The first relates to the inclusion of women in the university curriculum. The second addresses cultural perspectives - particularly international ones - and the third deals with supporting what is referred to in the US as professional development. In all these, I have had opportunities to braid these channels in my local settings and beyond.

Turning first to what we teach, I will offer an example from my early years at the University of Arizona. Though courses focusing on women and gender were being introduced into the curriculum, in the mid-1980s the Women's Studies faculty was also concerned with ensuring that other parts of the curriculum did not remain "gender blind." The initial strategy was to bring colleagues from a range of fields to participate in workshops in which each would commit to exploring the feminist scholarship in their discipline and to revising a course to integrate the new scholarship on women and gender. To extend 


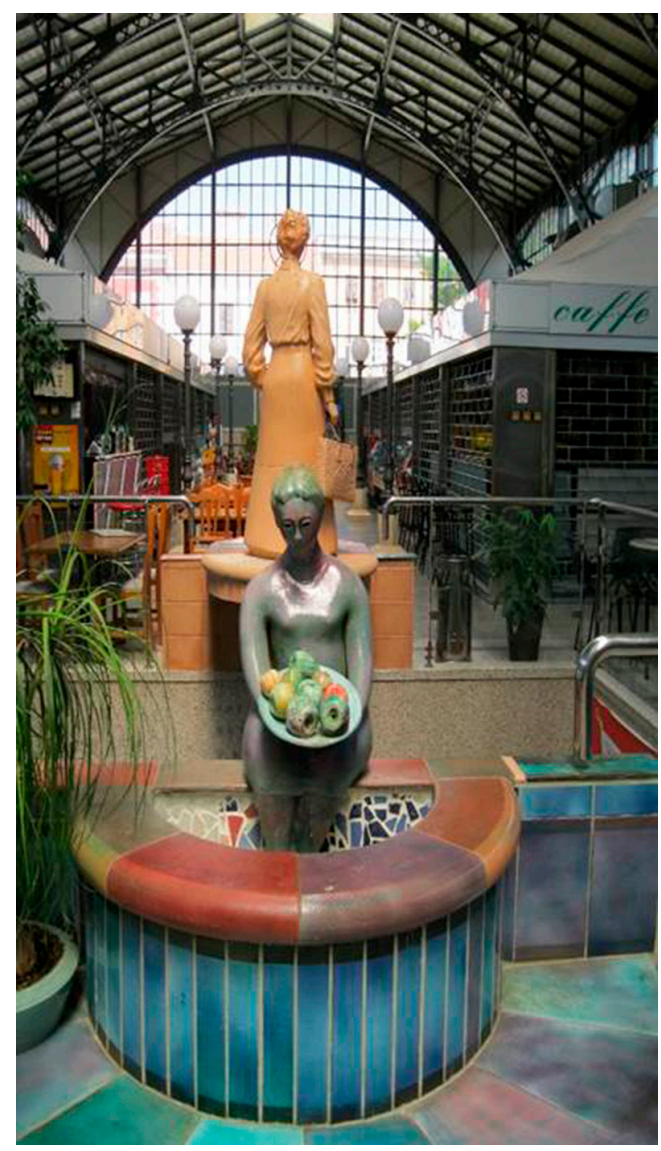

Figure 5. Women in a city market, Pula, Croatia. The class distinction of the figures of the women is evident in the contrast between the nude kneeling woman with the bowl of produce and the elegantly dressed standing figure of the woman shopping.

Source: Janice Monk, 2012.

that activity, which had become known as "curriculum integration," I was interested in also bringing in perspectives on women's lives around the world. With funding from the US Department of Education we recruited faculty members from universities in the SIROW region to revise or create new courses. Some results of that work were published (Monk and Newhall, 1992) giving examples from the social sciences and humanities and multiple world regions. Important themes included ways of rethinking categories, exploring diversity within as well as between places, and the challenges of dealing with students' assumptions as well as the teacher's confidence in introducing unfamiliar material. A later effort involved working with faculty members in several 
universities across the United States, and resulted in the book Encompassing Gender (Lay, Monk, and Rosenfelt, 2002).

Another endeavour involved straddling the international border between the US and Mexico to establish a long-term partnership for team research, teaching, and collaboration between academics and community health agencies. The connections were initiated by El Colegio de la Frontera Norte in Baja California and brought in El Colegio de Sonora and SIROW to address aspects of women's health in border communities. This team effort enabled reflections on challenges and approaches in managing and conducting sustained cross-national and cross-disciplinary endeavours, sharing our experiences of processes of collaboration as well as of empirical research. We reported in both Spanish and English-language publications, (Denman, Monk, and Ojeda de la Peña 2004; Monk, Manning, and Denman, 2002).

Also of value in developing perspectives has been the opportunity to host over the years at the University of Arizona scholars from multiple disciplines and countries. They have included, among other visitors, those from Australia, Azerbaijan, the UK, Iceland, India, Israel, New Zealand, Norway, Russia, South Africa and Switzerland, and, of course, Catalonia. We were delighted to have an array of geographers from the Autonomous University of Barcelona including Toni Luna, now at Universitat Pompeu Fabra, who came to Arizona for his PhD studies; to have sabbatical visits from Maria Dolors Garcia Ramon and Mireia Baylina, and shorter term visits from students including Alba Caballé and Soledad Morales.

Other examples have involved working nationally on educational change with professional geography organisations, both the Association of American Geographers (AAG) and also the National Council for Geographic Education. This work began in the late 1970s when three of us organised a project to recruit male geographers who were teaching introductory Human Geography courses to collaborate in creating teaching materials on women to include in their courses. Our product was a booklet of teaching resources entitled Women and Spatial Change (Rengert and Monk, 1983). Later, in the 1990s, under the leadership of Rickie Sanders and the National Council on Geographic Education, we organised a project for high school teachers in which they created sample teaching materials and pedagogical approaches in order to include content and strategies that are gender and racially-ethnically inclusive (Monk, Sanders, Killam Smith, Tuason, and Wridt, 2000).

I have also been able to collaborate in educational discussions via the International Geographical Union, first in its Commission on Geographical Education and subsequently in the Gender Commission. At its conference in Hungary and Romania in 2009, for example, we included discussions on teaching gender in post-socialist, neo-liberal contexts, with subsequent articles addressing challenges in Israel, the Netherlands, New Zealand, Romania, and Spain (Monk, 2011). Such experiences provide sustenance, 
inspiration, access to other world views, professional support, and personal friendships.

Most recently, since 2005, I have been active in initiatives organised by the Association of American Geographers and funded by the National Science Foundation and known collectively as the EDGE project, an acronym for "Enhancing Departments and Graduate Education." They involve research into how students and faculty members see their current studies; addressing such themes as the match or discordance in the visions of students and faculty members regarding the students' future careers, whether these be inside academia or in other areas (Monk, Foote, and Schlemper, 2012) and how students and faculty members interpret the concept of "diversity" (Schlemper and Monk, 2011)). Drawing on that research we have developed workshops, publications and online resources to support students and to recognise individual differences in their goals and life circumstances, and which are sensitive to the diversity in the student body in terms of gender, age, marital and family status, ethnicity, and domestic or international origin (Solem, Foote and Monk, 2009; 2012). We recognise both the challenges and stresses these students face in today's economic, social and technological circumstances; ones that differ from the experiences of the generations that currently hold academic appointments. The EDGE work has brought me into contact not only with academic geographers but with those engaged in applied fields in government, business, and nonprofit organisations.

If that work is looking forward, I cannot end this account without mentioning another area of research I especially enjoy - excavating the histories of women geographers in the US from the late nineteenth century and continuing into the 1970s. How did they envision their work? What challenges did they face, especially from male-dominated universities, and how did they contribute to education and society? In this research I have found fascinating archival material including correspondence, oral histories, teaching materials and publications, and visual evidence of the character of the institutions with which they worked. Beginning in the late 1980s, I began my own interviews with women whose careers had begun in the 1930s.

While they may have faced political, cultural and economic difficulties, the lives of the women I have studied illustrate their perseverance, accomplishment and significant professional contributions. I include not only the few women who worked in universities over those decades but especially the many who worked in teacher education institutions, or "normal schools" as they were initially known, and who outnumbered the male geographers in universities of their times (Monk, 2004). Beyond academia I have also looked at women who made important contributions in arenas that were more open to them, for example, as editors and librarians at the American Geographical Society in the first half of the $20^{\text {th }}$ century (Monk, 2003) and most recently to those "Washington Women" who had careers as geographers in US government agencies 
throughout much of the $20^{\text {th }}$ century. Here I offer just three examples of women of different generations who were engaged in challenging norms. Zonia Baber began in a normal school but then moved into the education department of the University of Chicago while maintaining her links with geography. She is recognised as the founder of the Chicago Geographical Society in the 1890s; her motives being to support school teachers and promotion of field experience. She was also an extraordinary social activist, pursuing causes that included peace, anti-racism, women's rights, internationalism, and environmentalism (Monk and Schmidt di Friedberg, 2011). Julia Shipman is representative of the women who also began teaching in normal schools, and in her case she went on to earn her PhD at age 46, realising that a doctorate was then being required for university appointments. The challenge however was that universities preferred to hire was they saw as "bright, young men". After a struggle in temporary university positions, she spent the remainder of her career at Mt. Holyoke, a prestigious private women's college, though she also taught for a year at a university in China (Monk 2004). Thelma Glass, one of the few African American women geographers of her era, taught in a historically black university in Alabama, but is also noted for her important political work in the Civil Rights movement of the 1960s. (George, Monk and Gaston, 2004).

I hope then that looking back also prompts us to look to the future with aspirations that are inclusive and creative - ones that value commitments to social change, international collaboration, and the pleasure and rewards that come from working together and that enable us to forge such good friendships and the intellectual stimulation that I have received.

\section{Bibliographic references}

Aitken, Stuart and Valentine, Gill (eds.) (2006). Approaches to Human Geography: Philosophies, People, and Practices. London, Thousand Oaks, CA and New Delhi: Sage Publications. <http://dx.doi.org/10.4135/9781446215432.n1>

BARNES, Trevor (2001). "Lives lived and lives told: Biographies of geography's quantitative revolution". Environment and Planning D: Society and Space. 19, 409-429. $<$ http://dx.doi.org/10.1068/d304>

Denman, Catalina; Monk, Janice and OJeda de la Peña, Norma (eds.) (2004). Compartiendo historias de fronteras: Cuerpos, géneros, generaciones y salud. Hermosillo, MX: El Colegio de la Frontera Norte.

Garcia Ramon, Maria Dolors and Monk, Janice (eds.) (1996). Women of the European Union: The Politics of Work and Daily Life. London: Routledge. <http://dx.doi.org/10.4324/9780203430361>

- (2007). Feminist Geographies Around the World. Belgeo 2007/3.

George, Sunita; Monk, Janice and Gaston, Juanita (2004). "Teachers for their times" In: Wheeler, J.O. and BrunN, S. (eds.). The South's Role in the Making of American Geography: Centennial of the AAG. Columbia, MD: Bellweather Publishing, 337-342. 
Jacobs, Susie (2010). Gender and Agrarian Reform. London and New York: Routledge. KIng, Lesley J. (ed.) (2007). North American Explorations: Ten Memoirs of Geographers from Down Under. Vancouver, BC: Trafford Press.

LaY, Mary M.; Monk, Janice and Rosenfelt, Deborah S. (2002). Encompassing Gender: Integrating International Studies and Women's Studies. New York: The Feminist Press at the City University of New York.

Monk, Janice (1974). "Australian aboriginal social and economic life: Some community differences and their causes”. In: Evenden, L.J. and Cunningham, F.F. (eds.). Cultural Discord in the Modern World. Vancouver: Tantalus, 157-174.

- (1992). "Gender in the landscape: Expressions of power and meaning". In: Anderson, Kay and Gale, Fay (eds.). Inventing Places: Studies in Cultural Geography. Melbourne: Longmans Cheshire, 123-138.

- (1994). "Place Matters: Comparative International Perspectives on Feminist Geography". The Professional Geographer, 46(3), 277-288. <http://dx.doi.org/10.1111/j.0033-0124.1994.00277.x>

- (2003). "Women's worlds at the American Geographical Society". The Geographical Review, 93(2), 237-257.

<http://dx.doi.org/10.1111/j.1931-0846.2003.tb00031.x>

- (2004). "Women, gender, and the histories of American geography". Annals of the Association of American Geographers, 94(1), 1-22. <http://dx.doi.org/10.1111/j.1467-8306.2004.09401001.x>

- (2011). "Politics and priorities: Placing gender in geographic education". International Journal of Geographical and Environmental Education, 20(3), 169-174. <http://dx.doi.org/10.1080/10382046.2011.588491>

Monk, Janice; Foote, Kenneth E. and Schlemper, Mary Beth (2012). "Graduate education in U.S. Geography.: Students career aspirations and faculty perspectives". Annals of the Association of American Geographers, 102 (6), 1432-1449. <http://dx.doi.org/10.1080/00045608.2011.601199>

Monk, Janice and Hanson, Susan (1982). "On not excluding half of the human in human geography". The Professional Geographer, 34, 11-23. <http://dx.doi.org/10.1111/j.0033-0124.1982.00011.x>

Monk, Janice; Manning, Patricia and Denman, Catalina (2002). "Seeking common ground: Collaboration in research and action at the Mexico-US border". Association of American Geographers Annual Meeting, Los Angeles.

Monk, Janice and Newhall, Amy W. (eds.) (1992). "Reaching for Global Feminism: Approaches to Curriculum Change in the Southwestern US”. Women's Studies International Forum, 14(4). Guest edited issue.

Monk, Janice and Schmidt di Friedberg, Marcella (2011). "Mary Arizona (Zonia) Baber". Geographers Biobibliographical Studies, 30, 58-79.

Monk, Janice; Sanders, Rickie; Killam Smith, Peg; Tuason, Julie and Wridt, Pamela (2000). "Finding a Way (FAW): A program to enhance gender equity in the K-12 classroom”. Women's Studies Quarterly, 28(3), 177-181.

Moss, Pamela (ed.) (2001). Placing Autobiography in Geography. Syracuse: Syracuse University Press.

Norwoood, Vera and Monk, Janice (eds.) (1987). The Desert Is No Lady: Southwestern Landscapes in Women's Writing and Art. New Haven: Yale University Press.

Rengert, Arlene and Monk, Janice (1983). Women and Spatial Change. Kendall Hunt: Dubuque Iowa. 
Samarasinghe, Vidyamali (2008). Female Sex Trafficking in Asia. London and New York: Routledge.

Schlemper, Mary Beth and Monk, Janice (2011). "Discourses on diversity: Perspectives from graduate programs in geography in the United States". Journal of Geography in Higher Education, 35(1), 23-46.

<http://dx.doi.org/10.1080/03098265.2010.499564>

Solem, Michael; Foote, Kenneth; Monk, Janice (eds.) (2009). Aspiring Academics. Upper Saddle River, NJ: Pearson/Prentice Hall.

- (2012). Practicing Geography. Upper Saddle River, NJ: Pearson/Prentice Hall.

Williams, Shelley (producer) (1995). The Desert Is No Lady. New York/Women Make Movies. 